University of San Diego

Digital USD

Spring 5-19-2015

\title{
The International Criminal Court in Crisis: Is Local Outreach the Route to Stability?
}

Taylor J. Kilpatrick

University of San Diego

Follow this and additional works at: https://digital.sandiego.edu/honors_theses

Part of the International Relations Commons

\section{Digital USD Citation}

Kilpatrick, Taylor J., "The International Criminal Court in Crisis: Is Local Outreach the Route to Stability?" (2015). Undergraduate Honors Theses. 4.

https://digital.sandiego.edu/honors_theses/4

This Undergraduate Honors Thesis is brought to you for free and open access by the Theses and Dissertations at Digital USD. It has been accepted for inclusion in Undergraduate Honors Theses by an authorized administrator of Digital USD. For more information, please contact digital@sandiego.edu. 


\title{
The International Criminal Court in Crisis:
}

\section{Is Local Outreach the Route to Stability?}

\author{
A Thesis \\ Presented to \\ The Faculty and the Honors Program \\ Of the University of San Diego
}

By:

Taylor Kilpatrick

Department of Political Science and International Relations

2015 
Abstract: The International Criminal Court is at the forefront of the international transitional justice realm today. Despite its omnipresence, there is a seemingly ceaseless succession of arguments against the Court. As this disapproval abounds, it effectively obscures the specific issues at hand. The strain on the interaction between global and local levels of justice within the scope of the ICC arguably underscores the entire crisis situation. More specifically, there is a seemingly unbridgeable distance, both physical and cultural, between the entity of the ICC and the local communities it purportedly serves. This paper seeks to address the absence of local narratives and genuine two-way discussion by assessing the ICC's current outreach and community engagement structure. Further, I explore the extent to which the ICC is paralyzed by its evaporating legitimacy and local perceptions of its inaccessibility, and ultimately make recommendations for its future. The Court's community outreach program needs to be completely rebuilt to incorporate active listening and a long-tem dialogue between the two realms. Meaningful contact builds mutual trust, and without it, any attempt at progress or reconciliation will be feckless. Only when the ICC makes these constructive changes can it emerge from the current turbulence with a positive legacy. 
The International Criminal Court represents a historic advancement in international criminal justice and the simplification of the response process to mass atrocities that are all too common throughout the world. The existence of a permanent tribunal system with a predetermined structure provides a sense of clarity for addressing mass atrocity at the international level. In its creation, the ICC extracted lessons, critiques and structures from the Nuremberg Trials and the International Criminal Tribunals for Yugoslavia and Rwanda in order to build a representative and stable entity. ${ }^{1}$ The Court now serves as a permanent beacon of the international standards of justice and human rights beyond any individual state, and aims to be a source of accountability for those expectations. ${ }^{2}$

Such an established and overarching judicial body has never existed before, making its future both intriguing and obscure. The fact that the ICC has no peers internationally makes interpreting its success and failure somewhat abstract and subjective. This is compounded by the fact that it has not yet been fifteen years since the Rome Statute was ratified in 2002, and it is still in a state of emergence and growth. Nonetheless, the ICC currently faces major criticism, to such severity that it has been labeled the "crisis" of the ICC. ${ }^{3}$ Because of constantly clashing objectives and expectations among states, the Court has arguably been in this crisis state since its inception. This makes the current concern of its viability less of a grave revelation.

\footnotetext{
${ }^{1}$ Peter Rosenblum, "Save the Tribunals: Salvage the Movement: A Response to Makau Mutua," Temple International and Comparative Law Journal, Vol. 11 (1997). ${ }^{2}$ Jeremy Sarkin, "Enhancing the legitimacy, status and role of the International Criminal Court globally by using transitional justice and restorative justice strategies," Interdisciplinary Journal of Human Rights Law, Vol. 6:1 (2011-2012), 85. ${ }^{3}$ Mark Kersten, "Yes, the ICC is in Crisis. It Always Has Been," Justice in Conflict, February 24, 2015, http://justiceinconflict.org/2015/02/24/yes-the-icc-is-in-crisis-italways-has-been/.
} 
However that does not detract from the immediate necessity to address the questionable future of the Court. ${ }^{4}$ In order to stabilize and ensure the longevity of the ICC, the heart of this crisis situation needs to be uncovered and resolved. However, there is an apparent trend to make sweeping criticisms and extreme statements about the Court's failure, rather than attempting to tackle the specific flaws.

Critic Adam Branch writes of the ICC, “...Its prosecutions have appeared politicized, partial, unpredictable and ineffective. It has been anti-democratic, secretive and dismissive of criticism or dissent.."5 He goes on to claim that the ICC is institutionalizing conflict and it has entirely failed to achieve any of its founding ideals. In direct contrast to arguments of the ICC's continual progress and the hope of universal justice and human rights, Branch argues that this is both untrue and undesirable. From his perspective, the ICC is founded upon unrealistic and noninclusive liberal assumptions and demands the conformity of all states. ${ }^{6}$ He is not alone in believing that the ICC is an unjust and unhelpful system, but the argument is concerning. The creation of this court marks a historical step and to call into question its viability as a whole is premature. While the Court's young age and unprecedented structure makes its future unclear, this is also reason enough to attempt to salvage and improve the system before condemning it to failure. However, my argument does not swing the pendulum in the absolute opposite direction and praise the ICC for inspiring a "regime of liberal peace" that will rise above all individual states and bring forth an

${ }^{4}$ Ibid.

5 Adam Branch, "Neither Liberal, Nor Peaceful? Practices of 'Global Justice' by the ICC" in A Liberal Peace? The Problems and Practices of Peacebuilding, ed. Susanna Campbell, David Chandler and Meera Sabaratnam (Zedd Books, 2011), 122.

${ }^{6}$ Ibid. 124. 
era of universal justice. ${ }^{7}$ To make such a claim would only reinforce the exact barrier that these radical criticisms have created.

The crisis of the ICC is based on a host of genuinely concerning actions and dilemmas that have been constantly overlooked. The issue is simply that the tactics for addressing such apprehensions continue to be unproductive. Nowhere in Branch's article does he suggest alternatives or critique the system in any constructive way. A major reason why international transitional justice as a whole, as exemplified in the ICC, has not successfully mobilized or incorporated criticisms is because of arguments such as Branch's. He and so many others become caught in the frenzy of condemnation and judgment, without assessing the situation with any specificity. The desire to make drastic claims and noteworthy assessments is a common barrier to action within the realm of Political Science and International Relations writing, one which has also paralyzed the ICC.

Dustin Sharp elucidates another source of immobility, with the threat of the entire field of international transitional justice becoming entangled in the uncertainty of the rhetoric. ${ }^{8}$ Emphasizing local ownership and incorporation of local values is prevalent among international organizations, however this heightened focus has so far only gleaned ambiguous declarations. Attempting to find a balance between "the global" and "the local" is a ceaseless game of tug-of-war, of which there is no definitive winner. There is a larger-scale necessity to more decisively and narrowly define transitional justice. This is a dilemma that no single international body can conclude. Nonetheless,

7 Ibid. 129.

8 Dustin Sharp, "Addressing Dilemmas of the Global and the Local in Transitional Justice," Emory International Law Review, Vol. 29 (2014), 5. 
the ICC finds itself riddled with this uncertainty as well.

Pinpointing individual issues with the International Criminal Court is a much more constructive mode of assessing the future of the Court. The ICC is certainly brimming with controversy. Beyond the fact that the international community will never wholly agree upon a single international justice system, or whether such an entity should even exist, the ICC faces continual criticism for its structure and for its actions. Aside from the absence of The United States, Russia and China from the ratified members, there are time and capacity restrictions, as well as miscommunications and inflated expectations that lead to feelings of insufficient results. ${ }^{9}$ Additionally, the financial struggle currently running rampant in the ICC is a crisis in itself. Implementing any changes is virtually impossible without sufficient funding or international backing. However, it is not productive to dwell on concerns of financial strains or support from powerful states when they are not the central problems at hand.

It is unsurprising that heightened expectations have accompanied this unprecedented court, but these expectations can also blind people to the obstacles and logistical challenges the ICC faces. In order to fully conduct an investigation into a country's horrific events, the prosecutor requires access to evidence, witnesses and alleged perpetrators, all of which requires the cooperation of the local government. While it is certainly essential and constructive to have national governments ingrained in the post-conflict justice process, this can also be highly limiting for the Court. This is

${ }^{9}$ Eric Stover, "Witnesses and the promise of justice in the Hague," in My Neighbor, My Enemy: Justice and Community in the Aftermath of Mass Atrocity, ed. Eric Stover and Harvey M. Weinstein, (Cambridge University Press 2004), 107. 
especially the case when government leaders are the purported instigators. The tradeoff between in-country access and one-sided prosecutions is not always accepted as true or complete justice.

This dilemma takes shape in the case of Uganda. The Ugandan government referred their case to the ICC in 2003 and an investigation into alleged war crimes and crimes against humanity during the civil war was officially opened in 2004. It was quickly revealed that the government's goal in initiating the case was to highlight the crimes of the Lord's Resistance Army (LRA) and avoid prosecution for their own questionable military actions. ${ }^{10}$ Although the ICC is committed to fair and complete justice, the investigations were severely limited by the cooperation of the national government. Quite overtly, the Ugandan government has threatened to withdraw its referral if its military personnel are subject to prosecution. ${ }^{11}$ The Prosecutor ultimately decided to move forward with investigations, despite their politicized and one-sided nature, because of the severity of the atrocities and the inability of the national government to adequately respond. This situation is compounded by Northern Ugandan civil society's almost immediate rejection of the Court's presence. ${ }^{12}$ While some progress has since been made, Marlies Glasius argues that the ICC's presence in Uganda has been completely wasteful, as neither peace nor justice has

\footnotetext{
${ }^{10}$ Marlies Glasius, "What is Global Justice and Who Decides? Civil Society and Victim Responses to the International Criminal Court's First Investigations," Human Rights Quarterly, Vol. 31 (2009), 507.

${ }^{11}$ Adam Branch, "Neither Liberal, Nor Peaceful? Practices of 'Global Justice' by the ICC" in A Liberal Peace? The Problems and Practices of Peacebuilding, ed. Susanna Campbell, David Chandler and Meera Sabaratnam (Zedd Books, 2011), 131.

12 Marlies Glasius, "What is Global Justice and Who Decides? Civil Society and Victim Responses to the International Criminal Court's First Investigations," Human Rights Quarterly, Vol. 31 (2009), 507.
} 
been attained.13 At the same time, while the majority of the arrest warrants have not yet lead to capture, their existence alone ignited a national discussion of accountability that has ultimately been productive and valuable. ${ }^{14}$ This Ugandan situation exemplifies the complex and often overwhelming nature of the ICC's crisis. There are no clear answers to many of the issues that the Court faces, yet the unprecedented potential and the permanence of this entity prompt me to delve deeper, in search of more conclusive steps for its future.

The permanent structure of the ICC that motivates perseverance and makes it easily replicable also creates controversy. Branch, along with numerous other critics, argues that the ICC is continuously imposing western justice on typically non-western countries. That the western, retributive justice system is favored by many of the most powerful states does not guarantee its superiority or its universal applicability. ${ }^{15}$ Using the same model of justice in every unique situation also has the potential to cloud its authenticity. However this criticism is in no way specific to the International Criminal Court; it is instead a concern of the threat of globalization and universalized justice as a whole. The ICC alone should not bare the full force of that judgment. It is ineffectual to make broad theoretical disputes the scapegoats for more substantive struggles that the ICC is facing. In order to affect constructive change, it is vital to look beyond these pervasive and unchangeable issues and confront the core of the ICC crisis.

\footnotetext{
${ }^{13}$ Ibid. 507-508.

14 Ibid. 508.

${ }^{15}$ Adam Branch, "Neither Liberal, Nor Peaceful? Practices of 'Global Justice' by the ICC" in A Liberal Peace? The Problems and Practices of Peacebuilding, ed. Susanna Campbell, David Chandler and Meera Sabaratnam (Zedd Books, 2011), 129.
} 
In the book, My Neighbor, My Enemy, Laurel Fletcher and Harvey Weinstein discuss international justice as it was applied in the International Tribunal for Former Yugoslavia, but their conclusions resonate with the ICC's struggles as well. They illuminate the heart of the ICC's crisis when they state that, "From the perspective of those living in the region, the ICTY was a world unto itself. The tribunal was removed physically, culturally and politically from those who would live most intimately with its success or failure. International justice and national social reconstructions occupied separate spheres." 16 This passage immediately clarifies the most critical aspect of the ICC's struggles, and the source of a myriad of its other problems: the physical and cultural distance between the ICC and the communities for which it aims to provide justice. Not only do locals often see the ICC as inaccessible because of the physical distance between The Hague in The Netherlands, and themselves, but also because of the cultural differences between western, retributive justice and their own traditional understanding.

For many, the ICC does seem to be "a world unto itself" because there is no meaningful impact on their community as a result of the investigations. In Eric Stover's interviews with locals, he highlights this as one of the most discouraging aspects of trials for the witnesses. Many felt abandoned and even more helpless when they returned home to find that the court did not alleviate their agony or their community's

\footnotetext{
${ }^{16}$ Laurel E. Fletcher and Harvey M. Weinstein, "A world unto itself? The application of international justice in the Former Yugoslavia," in My Neighbor, My Enemy: Justice and Community in the Aftermath of Mass Atrocity, ed. Eric Stover and Harvey M. Weinstein, (Cambridge University Press 2004), 33.
} 
degradation. ${ }^{17}$ In the face of a similar situation, a woman named Charity Kondile testified at the Truth and Reconciliation Commission in South Africa. She explains, "It is easy for Mandela to forgive-his life has changed; but for the woman in the shack, it is not possible." 18 She does not have the luxury to focus on reconciliation because she is faced with poverty and loss every single day. Especially because the ICC is restricted to such a small number of prosecutions, victims experience no measureable change in their daily lives, and therefore do not see any value in its existence. These victims feel voiceless in the system and disengaged from the entire process.

Such sentiments of detachment reduce the legitimacy of the ICC for local communities and discourage participation. A lack of local legitimacy has the potential to undermine the entire process. Logistically, witnesses and the government will be disinclined to cooperate, and even more importantly, the trials will not resonate with the community in any meaningful or enduring way. The locals' distrust and invalidation of the investigations is compounded by their discomfort with these foreign notions of formal prosecutions. ${ }^{19}$ All of this makes citizens more malleable for those who are outspoken against the Court. When locals already feel rejected or ignored by the ICC, an alternate source of authority, such as the national government, can more easily convince citizens that the ICC is harmful and exploitative. This is exactly the scenario that emerged in Kenya. While opinion surveys indicate that local support for

17 Eric Stover, "Witnesses and the promise of justice in the Hague," in My Neighbor, My Enemy: Justice and Community in the Aftermath of Mass Atrocity, ed. Eric Stover and Harvey M. Weinstein, (Cambridge University Press 2004), 107.

${ }^{18}$ Antjie Krog, Country of My Skull: Guilt, Sorrow and the Limits of Forgiveness in the New South Africa (Random House South Africa, 1998), 146.

${ }^{19}$ Njonjo Mue, "Policy Brief: Enhancing the Societal Impact of International Criminal Tribunals," Impunity Watch, February 2015, 4. 
the ICC's presence was initially high, ${ }^{20}$ as the investigation continued, approval dwindled and the Kenyan government was quick to replace it with anti-tribunal propaganda. ${ }^{21}$ President Kenyatta campaigned as a supporter of the ICC, but at the same time he, somewhat more subtly, constantly portrays the Court as a source of western imperialism that threatens to breach Kenya's freedom. Now, disapproval of the investigations has become so severe that personnel are threatened and participants fear for their safety. ${ }^{22}$

When any international state or entity enters a post-conflict area in hopes of bringing about justice and reconciliation, its presence is not easily welcomed. The western methods and the lack of interpersonal and intercultural communication obscure these motives. Perception has the power to sway entire communities, especially when the presence of outsiders implies local inferiority. Even before the ICC takes action to seek justice, the community may have resentment and distrust for the Court. This is heightened by the fact that the ICC employs standardized, western forms of retributive justice. While this model allows for greater longevity and efficiency of the court system, it also appears to leave little space for local involvement or traditions. ${ }^{23}$

Human rights activists often claim that there is great "therapeutic value" in testifying in front of a tribunal and recalling the horrific events. Victims are recognized

20 Ibin. 8.

21 "Perceptions and Realities: Kenya and the International Criminal Court," Human Rights Watch, November 14, 2013, http://www.hrw.org/news/2013/11/14/perceptions-and-realities-kenya-andinternational-criminal-court\#5.

22 Ibin.

${ }^{23}$ Dustin Sharp, "Addressing Dilemmas of the Global and the Local in Transitional Justice," Emory International Law Review, Vol. 29 (2014), 2. 
for their struggles and can therefore move forward with their lives. ${ }^{24}$ However, in reality, this sense of healing or catharsis cannot be attained from one witness testimony or any one event. Such claims that telling your story will absolve you of your pain creates unreasonable expectations for the court and will only lead to a sense of desertion. This disappointment is compounded when witnesses and victims feel disconnected from the Court. Eric Stover catalogues opinion surveys in My Neighbor, My Enemy and explains that it is common for witnesses to feel abandoned by the court because they never receive information about their cases and they cannot easily access the tribunal's personnel. This is not to say that expectations for the ICC simply need to be lowered, for there is still great value in participating in post-conflict justice. Instead, the wishful thinking of the Court's healing powers needs to be merged with realistic outcomes.

Mental health professionals clarify that trauma recovery takes time, and also requires a sense of security, reconnection with peers and personal control. A tribunal alone cannot accomplish these results. Additionally, a perhaps more attainable necessity is open and ongoing lines of communication between victims and the Court that more completely encapsulate the needs of the individuals and their communities. ${ }^{25}$ Open discussion and the opportunity to participate and be heard are all essential for the local communities and victims to see the justice system as legitimate. While it is not possible to completely change the prosecution process or to try people

${ }^{24}$ Eric Stover, "Witnesses and the promise of justice in the Hague," in My Neighbor, My Enemy: Justice and Community in the Aftermath of Mass Atrocity, ed. Eric Stover and Harvey M. Weinstein, (Cambridge University Press 2004), 107.

25 Ibin. 108. 
far beyond the capacity of the Court, the ICC does have the potential to more widely engage the community and listen to the daily stresses of witnesses and other victims. In the inarguably globalized world, any effort to reengage local opinions and traditions as well as community participation will involve international influence. Especially as transitional justice and international criminal justice ideologies continue to evolve, the international community will increasingly participate in local breaches of justice. Eliminating the ICC or other international justice organizations in favor of unique local responses would not have the desired effect of invigorating local ownership because inter-state influence has become the standard in how the global sphere functions. No single organization is responsible for this shift towards globally interconnected justice. This moment in the narrative of justice has the opportunity to be a crossroads, but eradicating the ICC is not the path that will lead to any effectual change. Instead, the systems already in place must be refined and reexamined in order to embrace the globalized world in a way that can also highlight and cherish local engagement and culture.

While there are certainly benefits to a consistent and structured court system like the ICC, local outreach is a vital complement to that existing construct, and an opportunity to more effectively listen to and incorporate local voices and concerns into post-conflict justice. In fact, the Court already has the framework to more overtly and fully incorporate local voices into the system. The ICC is currently severely detached from the communities that it aims to assist, however it has the structure, within the Rome Statute, to make constructive change without compromising the momentous strides it has taken in the realm of international criminal justice. 
The Preamble of the Rome Statute establishes the foundation for an inclusive and responsive interaction with local communities: "The States Parties to this Statute, [are] conscious that all peoples are united by common bonds, their cultures pieced together in a shared heritage, and... [they are] enhancing international cooperation."26 More specifically, community outreach programs fall under the jurisdiction of the Registry, which is established in Article 43 of the Rome Statute. The program utilizes a variety of communication tools, including town-hall meetings, interactive radio and television events, and face-to-face meetings. ${ }^{27}$ While community outreach is not overtly addressed in the Rome Statute, the Registry provides the basis to carryout these interactive and educational dialogues, with additional efforts from the Office of the Prosecutor as well. ${ }^{28}$ In the ICC's Integrated Strategy for External Relations, Public Information and Outreach, the term outreach is defined as, "a process of establishing sustainable, two-way communication between the Court and communities affected by the situations that are subject to investigations or proceedings." 29 This definition, in tandem with the platform for outreach in the Registry, is encouraging because the framework for prioritizing active listening, embracing cultural diversity and two-way dialogue already exists. The frailty of the local outreach system within the ICC is not structural, there is simply not enough emphasis placed on this facet of the Court, or transitional justices efforts in general.

${ }^{26}$ UN General Assembly, Rome Statute of the International Criminal Court, July 1998, http://www.icc-cpi.int/iccdocs/PIDS/publications/RomeStatutEng.pdf 27 "The Outreach Debate," ICCforum.com, Office of the Prosecutor, last modified February 2015, http://iccforum.com/outreach.

28 Ibin.

${ }^{29}$ ICC Integrated Strategy for External Relations, Public Information and Outreach, available at: http://www.icc-cpi.int/NR/rdonlyres/425E80BA-1EBC-4423-85C6D4F2B93C7506/185049/ICCPIDSWBOR0307070402 IS En.pdf. 
An ongoing debate within the realm of transitional justice is how to balance retributive and restorative justice efforts. While the ICC subscribes to retributive justice measures, a common criticism of trial systems in general is their lack of attention to the interests and voices of victims, which in turn can weaken societal impacts and local participation. Despite the confines of retributive systems, the ICC is often expected to impart long-term community reconnection and forgiveness, in addition to attaining justice and accountability across the entire country. The Court has been attempting to reach a societal impact that is entirely beyond its framework. While these unreasonable expectations exceed the ability of any international entity, a rejuvenated ICC outreach program makes movement towards these lofty standards more feasible. ${ }^{30}$

The ICC has the potential to expand beyond the confines of the archetypal court model and reach a higher level of local engagement by way of an improved outreach program. While it is unreasonable to call for a complete synthesis of retributive and restorative justice strategies, the ICC, as an unparalleled international body, has the capability to extend into the priorities of restorative justice by reframing community outreach. In fact, Jeremy Sarkin argues that the ICC should play a much greater role outside the confines of prosecutions. The Court has the ability to "set the standard of retributive justice in the international, regional and domestic contexts, but it can also have a critical role beyond simply prosecuting..." 31 While I do not argue that the ICC

\footnotetext{
${ }^{30}$ Njonjo Mue, "Policy Brief: Enhancing the Societal Impact of International Criminal Tribunals," Impunity Watch, February 2015, 2.

31 Jeremy Sarkin, "Enhancing the legitimacy, status and role of the International Criminal Court globally by using transitional justice and restorative justice strategies," Interdisciplinary Journal of Human Rights Law, Vol. 6:1 (2011-2012), 84.
} 
should entirely encapsulate the international human rights and restorative justice movement, I agree with Sarkin to the extent that the Court needs to breach the purely retributive model and incorporate restorative ideologies. Restorative justice is unique in its complete emphasis on extending beyond politics, rebuilding and reconnecting the community. ${ }^{32}$ The restoration of relationships and centralized focus on victims are characteristics that retributive systems generally lack. This restorative focus on victim participation complements the importance of accountability for the retributive model. Justice incorporates more than punishment for crimes and can only be genuinely successful when it is addressed in a manor that includes retribution, redistribution and restoration. ${ }^{33}$ By taking a broader perspective on the potential of its local outreach program, the ICC can work towards an entirely new level of local legitimacy, participation, and a voice for victims.

Current ICC local outreach efforts are not granted sufficient focus within the trial process as a whole. ICC representatives entering local communities are inexperienced and inadequately trained for their role in facilitating discussion, education and acceptance of the Court. Personnel do not receive instruction specifically catered to the culture in which they will be working, nor do they necessarily have extensive conflict-resolution or intercultural communication training. ${ }^{34}$ The setbacks are exacerbated by the short-term nature of existing outreach methods. Each community is treated as another line on a checklist, without allowing for extended interactions or mutual listening between parties. The priorities are the

32 Ibin. 88.

33 Ibin. 89.

34 "Improving the Effectiveness of International Lawyers in Rule of Law \& Transitional Justice Projects," Lawyers, Conflict and Transition Project, February 2015, 10. 
efficiency and breadth of the outreach, rather than depth or impactful dialogue.

Outreach can never be effective if the western ICC representatives go into villages with a translator, make a statement about the court proceedings en masse, and then move onto the next village. This only fosters a view that the ICC is apathetic and demeaning. The entire methodology of community outreach today perpetuates the cultural distance between ICC proceedings and local communities. This is an area in which Adam Branch's argument against the ICC resonates, because he is equally critical of the ICC's previous attempts at 'victim participation' and 'local outreach.' Currently, these systems lack the credibility and weight to impact the trial process in any meaningful way. Instead the terms are thrown around in the ICC's efforts to create an impression of community engagement. ${ }^{35}$ In actuality, the ICC maintains a reputation of nontransparency and inaccessibility.

Financial limitation is understandably one of the greatest concerns in implementing heightened outreach efforts, as it will definitely be a more resourceintensive process. Today, the ICC's budget and staff is equivalent to that of the International Criminal Tribunal for Former Yugoslavia, despite the fact that the ICC has to duplicate the process nine times over, in addition to preliminary investigations. ${ }^{36}$ However, the ICC's engagement efforts lack functionality and potency in their current form, so investing more time and resources into outreach is a warranted attempt to alleviate the crisis. An improved outreach program has the potential to ultimately

${ }^{35}$ Adam Branch, "Neither Liberal, Nor Peaceful? Practices of 'Global Justice' by the ICC" in A Liberal Peace? The Problems and Practices of Peacebuilding, ed. Susanna Campbell, David Chandler and Meera Sabaratnam (Zedd Books, 2011), 126.

${ }^{36}$ Njonjo Mue, "Policy Brief: Enhancing the Societal Impact of International Criminal Tribunals," Impunity Watch, February 2015, 3. 
increase the effectiveness of the entire trial process by way of heightened perceptions of legitimacy, willingness to participate and intercultural understanding. Engaging with the affected communities can spur more accepting and participatory attitudes towards court proceedings and international reconciliation efforts as a whole.

The systemized dialogue and intercultural learning necessary to mobilize the ICC is already established in the Registry and is complimented by the redoubled efforts of the Office of the Prosecutor just this year. Prosecutor Fatou Bensouda has specifically made local outreach a topic of focus for the Court from February to June 2015. She is especially interested in employing social media and other technology to "enhance understanding of the Court's mandate and activities." 37 She asks the questions, "How can the ICC improve its outreach and public information activities?" and "How best can specific audiences be reached?"38 It is encouraging to learn that the ICC is specifically asking how it can overcome the current challenges of outreach and this acknowledgement will hopefully spur movement towards a revised system. However, local outreach as it is currently understood within the ICC, is entirely centered on educating the public on court proceedings and managing expectations. ${ }^{39}$ The current scope is very narrowly focused on these goals, and while it is beneficial to retain clear and succinct objectives, in the case of the ICC's outreach, those objectives are simply too narrow to affect any change. If your only interaction with the Court is an educational meeting or radio broadcast that tries to convince you of the merits of a foreign and distant tribunal system, it seems unlikely that you will be convinced of its

37 "The Outreach Debate," ICCforum.com, Office of the Prosecutor, last modified February 2015, http://iccforum.com/outreach.

38 Ibin.

${ }^{39}$ Ibin. 
benefits to your daily life. It is equally important that outreach is neutral and nonpolitical, so as not to serve as propaganda of equitable desperation as the national governments. ${ }^{40}$ This is not to say that informational events and social media interactions are entirely negative or disposable; they are however insufficient.

There is space to reinterpret and broaden the current definition, to more accurately represent the need, but it is important to make the distinction between current and prospective interpretations before moving forward. Allocating greater resources and emphasis towards existing community outreach methods does not constitute a sufficiently revised system. This is clarified by the existence of The Strategic Plan for Outreach of the International Criminal Court, a report published in September 2006 that significantly increased the budget for the outreach program. ${ }^{41}$ Despite this hopeful step, nothing genuinely changed on the ground, making the entire plan fruitless. ${ }^{42}$ While gaining attention and fiscal support is vital to reinvigorating the Court, it is in no way a sufficient answer. Before financial support can have any impact at the local level, the outreach program first needs to be reinterpreted and expanded.

As a first step, the outreach program requires well-trained professionals who have both country-specific knowledge and a longer presence in each location. One of the central reasons why the ICC's local outreach initiatives have been feckless thus far is the lack of any effort to learn about the local culture they are serving. Those

\footnotetext{
${ }^{40}$ Njonjo Mue, "Policy Brief: Enhancing the Societal Impact of International Criminal Tribunals," Impunity Watch, February 2015, 7.

${ }^{41}$ Assembly of States Parties, Strategic Plan for Outreach of the International Criminal Court (ICC- ASP/5/12), September 262006.

42 Marlies Glasius, "What is Global Justice and Who Decides? Civil Society and Victim Responses to the International Criminal Court's First Investigations," Human Rights Quarterly, Vol. 31 (2009), 510.
} 
responsible for reaching out to local communities need to understand and convey that as foreigners, they lack a complete knowledge of the local culture and judicial customs. Beyond that, they must express a desire to learn from and participate in this culture. Rather than retaining the barrier of cultural distance, those involved in the outreach program can bring the two groups together, while at the same time educating the locals about the ICC process..$^{43}$ Informational events that detail the structure, proceedings and impacts of the ICC continue to be vital to building legitimacy; but these events should evoke an atmosphere of dialogue and conversation rather than a lecture. This discussion-based setting itself facilitates greater engagement because it provides direct access to the Court and a space to express personal interests, but its value extends even beyond this. On a national scale, this modified outreach program indicates that the ICC is not in fact as aloof or patronizing as perceptions suggest. Simply expressing a desire to build an interconnected relationship of mutual respect and learning indicates to the public that the ICC does in fact aim to support them.

Depending on the capacity of the program, there may be separate ICC personnel with specialties, or one individual may be responsible for fulfilling multiple roles. All resource limitations aside, there would ideally be a team in which specialists focus on face-to-face educational meetings, mass media informational marketing, or counseling and conflict-resolution. While such a comprehensive team is not realistic within every country and investigation, experts in intercultural communication, counseling and conflict-resolution, comparable to psychologists, are essential. Individualized dialogue between local victims and western visitors can build invaluable connections and

43 "Improving the Effectiveness of International Lawyers in Rule of Law \& Transitional Justice Projects," Lawyers, Conflict and Transition Project, February 2015, 6. 
promote a mentality of listening and empathy. Bringing these specialized and intimate conversations forward as a central strategy of international justice is both necessary and encouraging, but it cannot be the only strategy. A more structured and detached body such as the ICC is a necessary compliment to these localized methodologies. ${ }^{44}$ When these two facets of justice and reconciliation coexist within the same entity, they have the potential to revolutionize the entire paradigm of international criminal justice. As I previously discussed, retributive and restorative methodologies have traditionally been entirely segregated from one another in practice. However the ICC, an organization with a constant international spotlight, can reshape the interaction between the two modes of justice by way of more robust and involved outreach.

By redeeming the Court's legitimacy, opposing parties who fear prosecution will have a much more difficult time dissuading locals. President Kenyata's propaganda in Kenya would not so easily take hold and discourage participants if the ICC had a clear presence and desire to listen. ${ }^{45}$ The concept of legitimacy within transitional justice, as outlined by Jaya Ramji-Nogales, incorporates both sociological and legal dimensions. Legitimacy is an "ethically normative belief" with which humankind associates virtue and value that warrants dictating their actions. ${ }^{46}$ Legally, "that which is lawful is legitimate," while sociologically, it is seen as public reward or social guarantees beyond

\footnotetext{
44 Ibin.

45 "Perceptions and Realities: Kenya and the International Criminal Court," Human Rights Watch, November 14, 2013, http://www.hrw.org/news/2013/11/14/perceptions-and-realities-kenya-andinternational-criminal-court\#5.

46 Jaya Ramji-Nogales, "Designing Bespoke Transitional Justice: a Pluralist Process Approach," Michigan Journal of International Law, Vol, 32:1 (2010), 12.
} 
personal gains of any kind.$^{47}$ Both facets of legitimacy are enhanced in this remodeled outreach program. While retaining the educational aspect that asserts the legal legitimacy of the body, social legitimacy is achieved more gradually, by way of interpersonal dialogue and listening.

With greater local legitimacy comes greater participation. Victim participation is inherent in any ICC success and societal impact. As South African Archbishop Desmond Tutu explains, "In the African Weltanschauung, a person is not basically an independent, solitary entity. A person is human precisely in being enveloped in the community of other human beings, in being caught up in the bundle if life. To be... is to participate." 48 Any level of participation in the justice and dialogue provided by the ICC allows victims to reengage in their community and reconcile. Even passive participation prompts acceptance of the trial process and societal reengagement that will allow victims to normalize their daily lives once again. ${ }^{49}$

It is important to clarify that I am not making the argument that local outreach has the leverage to turn the entire ICC crisis on its head and completely solve the international debate over local engagement. There are limitations to its impact and therefore must be accompanied by additional efforts to improve the functionality of the ICC. For example, the debate of the African bias is one that urgently needs to be addressed. While it is inarguable that the ICC has exclusively conducted investigations in Africa, the motivations behind these decisions are unclear. This is a complex and

47 Ibin.

${ }^{48}$ Antjie Krog, Country of My Skull: Guilt, Sorrow and the Limits of Forgiveness in the New South Africa (Random House South Africa, 1998), 143.

${ }^{49}$ Njonjo Mue, "Policy Brief: Enhancing the Societal Impact of International Criminal Tribunals," Impunity Watch, February 2015, 5. 
controversial dilemma, but if it is not explicitly confronted, it has the potential to tear down the entire ICC. If the African Union member countries did in fact leave, the ICC almost certainly could not continue to exist because the African Union represents a majority of the Court's 123 members. 50

Additionally, not every application of this outreach program will have comparable or entirely successful results, an issue that may improve with time, but will never be eliminated. Nor will every individual consider the program a satisfactory attempt at progress. Individuals may be dissatisfied because the Court "does not represent their narrative of conflict." 51 Additionally, many disagree with the broader notion of universalized, liberal, international justice and therefore cannot be persuaded to approve of the ICC. 52

I do argue that cultivating this local outreach initiative has the potential to pull the ICC out of its current spiral towards desolation. Mutual understanding and communication is critical to progressing towards a stable relationship between the global and local spheres. ${ }^{53}$ This is why outreach should begin as early as possible, in the preliminary investigation stage of the case. ${ }^{54}$ Even before the ICC and local leaders can argue over the methods of the investigation and the extent of the ICC's access to the country, an open dialogue of the system itself must take place. Not only does it

${ }^{50}$ Jaya Ramji-Nogales, "Designing Bespoke Transitional Justice: a Pluralist Process Approach," Michigan Journal of International Law, Vol, 32:1 (2010), 44-45.

${ }^{51}$ Njonjo Mue, "Policy Brief: Enhancing the Societal Impact of International Criminal Tribunals," Impunity Watch, February 2015, 4.

52 Ibin.

${ }^{53}$ Marlies Glasius, "What is Global Justice and Who Decides? Civil Society and Victim Responses to the International Criminal Court's First Investigations," Human Rights Quarterly, Vol. 31 (2009), 509-510.

${ }^{54}$ Njonjo Mue, "Policy Brief: Enhancing the Societal Impact of International Criminal Tribunals," Impunity Watch, February 2015, 8. 
initiate a mutual relationship, but is also ensures that misinformation and rumors cannot fill the void. Facilitating a relationship of reciprocal listening and teaching is integral to building a successful international presence. This involves active listening and willing participation from both the ICC representatives and the local community. Initiating widespread participation is a challenging task in itself, and likely why there has been a communication void in the past, but it is the keystone of impactful justice and therefore worthy of extensive efforts.

While local outreach and heightened communication between the locals and the intervening parties has the capacity to greatly heighten cross-cultural understandings and more efficient judicial proceedings, outreach efforts can also exacerbate the problem. If done in a half-hearted, incomplete or superficial manner, as has essentially been the case in the past, outreach efforts can reinforce the perception of western imperialism. Outreach must be done sensitively, carefully and openly, all of which will be somewhat unique to each intervention situation. 55

In his article, Save the Tribunals; Salvage the Movement, Peter Rosenblum argues, "The Nuremberg and Tokyo prosecutions were...carried out with more than a hint of hypocrisy... Nevertheless, the Nuremberg Trials in particular contributed to an ideal. Warts and all, they are part of the international human rights corpus, enabling the adoption of new standards for the protection of civilians." ${ }^{56}$ Just as Rosenblum defends Nuremberg against the flurry of critics, and just as its positive legacy persists today as progress towards improved justice and human rights, I argue that the ICC can

55 "Improving the Effectiveness of International Lawyers in Rule of Law \& Transitional Justice Projects," Lawyers, Conflict and Transition Project, February 2015, 6.

${ }^{56}$ Peter Rosenblum, "Save the Tribunals: Salvage the Movement: A Response to Makau Mutua," Temple International and Comparative Law Journal, Vol. 11 (1997), 195. 
and will endure as an equally momentous stepping stone towards accepted and inclusive standards of international criminal justice. It is absolutely vital to not let the swath of criticisms of the ICC detract from affecting progress and recognizing potential. Through the complexities and the past failures, the ICC is an impressive and entirely unique entity, one that deserves more credibility and buttressing. Ultimately, energizing and recasting the ICC's local outreach program will serve as a facilitator for local participation, active listening and enhanced legitimacy. These efforts will collectively bridge the cultural divide between the ICC and local communities. This renewed outreach will effectively alleviate the paralysis that currently bars the Court from stepping into the future and achieving the original expectations envisioned for the International Criminal Court. 


\section{Bibliography}

Assembly of States Parties, Strategic Plan for Outreach of the International Criminal Court (ICC- ASP/5/12). September 26 2006. Available at: http://www.icccpi.int/NR/rdonlyres/FB4C75CF-FD15-4B06-B1E3 E22618FB404C/185051/ICCASP512_English1.pdf

Branch, Adam. “Neither Liberal, Nor Peaceful? Practices of 'Global Justice' by the ICC." In A Liberal Peace? The Problems and Practices of Peacebuilding, 2008, edited by Susanna Campbell, David Chandler and Meera Sabaratnam, 121137. London: Zedd Books, 2011.

Fletcher, Laurel E. and Harvey M. Weinstein. "A world unto itself? The application of international justice in the Former Yugoslavia." In My Neighbor, My Enemy: Justice and Community in the Aftermath of Mass Atrocity. Edited by Eric Stover and Harvey M. Weinstein, 29-48. New York: Cambridge University Press, 2004.

Glasius, Marlies. "What is Global Justice and Who Decides? Civil Society and Victim Responses to the International Criminal Court's First Investigations." Human Rights Quarterly, Vol. 31 (2009): 496-520.

ICC Integrated Strategy for External Relations, Public Information, and Outreach. Available at: http://www.icc-cpi.int/NR/rdonlyres/425E80BA-1EBC-442385C6-D4F2B93C7506/185049/ICCPIDSWBOR0307070402_IS_En.pdf.

"Improving the Effectiveness of International Lawyers in Rule of Law \& Transitional Justice Projects." Lawyers, Conflict and Transition Project. February 2015.

Kersten, Mark. "Yes, the ICC is in Crisis. It Always Has Been." Justice in Conflict. 
February 24, 2015. http://justiceinconflict.org/2015/02/24/yes-the-icc-isin-crisis-it-always-has-been/.

Krog, Antjie. Country of My Skull: Guilt, Sorrow and the Limits of Forgiveness in the New South Africa. South Africa: Random House, 1998.

Mue, Njonjo. "Policy Brief: Enhancing the Societal Impact of International Criminal Tribunals." Impunity Watch. February 2015.

"Perceptions and Realities: Kenya and the International Criminal Court." Human Rights Watch. November 14, 2013. http://www.hrw.org/news/2013/11/14 /perceptions-and-realities-kenya-and-international-criminal-court\#5. Ramji-Nogales, Jaya. “Designing Bespoke Transitional Justice: a Pluralist Process Approach." Michigan Journal of International Law, Vol, 32:1 (2010): 1-72. Rosenblum, Peter. "Save the Tribunals: Salvage the Movement: A Response to Makau Mutua." Temple International and Comparative Law Journal, Vol. 11 (1997): 189-197.

Sarkin, Jeremy. "Enhancing the legitimacy, status and role of the International Criminal Court globally by using transitional justice and restorative justice strategies." Interdisciplinary Journal of Human Rights Law, Vol. 6:1 (20112012): 83-101.

Sharp, Dustin. "Addressing Dilemmas of the Global and the Local in Transitional Justice." Emory International Law Review, Vol. 29 (2014): 71-117.

Stover, Eric. "Witnesses and the promise of justice in the Hague." In My Neighbor, My Enemy: Justice and Community in the Aftermath of Mass Atrocity. Edited by Eric Stover and Harvey M. Weinstein, 104-120. New York: Cambridge 
University Press, 2004.

"The Outreach Debate." ICCforum.com, Office of the Prosecutor. Last modified February 2015. http://iccforum.com/outreach.

UN General Assembly. Rome Statute of the International Criminal Court (last amended 2010). July 1998. ISBN No. 92-9227-227-6. Available at: http://www.icc-cpi.int/iccdocs/PIDS/publications/RomeStatutEng.pdf. 